\title{
15
}

\section{PERLINDUNGAN TERHADAP ANAK KORBAN TRAFFICKING}

\author{
Oleh: \\ Anis Soraya, Binahayati Rusyidi, \& Maulana Irfan
}

Email:

anissoraya25@gmail.com; titirusyidi@gmail.com;mirfan@gmail.com

\begin{abstract}
Abstrak
Anak adalah seseorang yang belum berusia 18 (delapan belas). Anak sebagai manusia berusia 0-18 tahun merupakan individu yang masih dalam masa perkembangan fisik, mental, maupun intelektual. Anak memang rentan menjadi sasaran tindak kekerasan dan perdagangan manusia. Beberapa hal yang menjadi faktor pendorong terjadinya perdagangan anak diantaranya; faktor ekonomi keluarga, rendahnya tingkat pendidikan anak dan keluarga, serta kurangnya kepedulian orangtua terhadap pengurusan administrasi anak seperti pembuatan akta kelahiran sehingga menyebabkan mudahnya terjadi perdagangan manusia karena korban tidak memiliki identitas. Perdagangan orang (Trafficking) adalah tindakan merekrut, mengirim, memindahkan, menampung atau menerima orang untuk tujuan eksploitasi baik di dalam maupun di luar negeri dengan cara kekerasan ataupun tidak. Anak memiliki hak khusus menurut hukum internasional dan hukum Indonesia dan Pemerintah dalam hal ini memiliki kewajiban untuk melindungi anak-anak dari kejahatan perdagangan manusia. Di dalam Konvensi Hak-hak Anak (KHA), ditegaskan bahwa anak berhak mendapatkan perlindungan dari penculikan, perdagangan dan penjualan anak untuk tujuan atau dalam bentuk apapun (pasal 35). Pemerintah Indonesia telah melakukan usaha-usaha untuk mencegah dan menanggulangi masalah perdagangan manusia dengan beberapa cara seperti dibentuknya undang- undang no 21. Tahun 2007, Tentang pemberantasan tindak pidana perdagangan orang, Undang-Undang No. 23 Tahun 2002 tentang Perlindungan Anak, dan pengadaan RPSA atau Rumah Perlindungan Sementara Anak. Ditingkat masyarakat, hendaknya ada kampanye dan pendidikan tentang perdagangan anak serta usaha-usaha untuk melawannya.
\end{abstract}

Kata kunci : anak, hak, perlindungan, kekerasan, trafficking

\section{Pendahuluan}

Anak sebagai manusia yang sedang tumbuh dan berkembang, baik fisik mental maupun intelektualnya. Pada masa perkembangan tersebut setiap anak sedang berusaha mengenal dan mempelajari nilai-nilai yang berlaku di masyarakat.Kondisi anak-anak tersebut sangat rentan untuk disalahgunakan oleh orang yang lebih dewasa.Salah satu penyalahgunaan terhadap anak adalah dengan memperdagangkan mereka. Hal ini juga dijelaskan oleh Irwanto dalam bukunya "Perdagangan Anak di Indonesia" pada tahun 2001 yang mengatakan bahwa anak, individu yang masih tergantung pada orang dewasa cenderung tidak dapat bertindak membela diri dan mengambil keputusan sendiri sehingga cenderung rentan menjadi korban penyalahgunaan anak oleh pihak yang tidak bertanggungjawab.

Data UNICEF menyebutkan setiap tahun ada sekitar 1,2 juta anak di dunia menjadi korban perdagangan anak. Di Indonesia, sebanyak 100.000 anak menjadi korban perdagangan anak setiap 
tahun, dan dari jumlah tersebut, 40.000 hingga 70.000 di antaranya menjadi korban prostitusi. Perdagangan anak dewasa ini semakin hari semakin mengkhawatirkan.

Korban trafficking pada umumnya adalah anak-anak dan perempuan di bawah umur yang mana korbannya adalah mereka yang mengalami kesulitan dalam bidang perekonomian. Traffiking ialah salah satu bentuk masalah sosial yang memiliki dampak negatif sangat besar terhadap kondisi psikologi korban trafficking. Perdagangan manusia adalah bentuk modern dari perbudakan.Korban perdagangan manusia harus mengalami kekerasan, pemalsuan, atau pemaksaan untuk tujuan eksploitasi seksual atau perburuhan paksa. Korbannya adalah anak-anak kecil, remaja, pria dan wanitaAnak-anak korban perdagangan manusia sering kali dieksploitasi untuk tujuan seksual, termasuk prostitusi, pornografi, dan wisata seks. Mereka juga dieksploitasi untuk perburuhan paksa, termasuk dijadikan pembantu rumah tangga, bekerja di pabrik dengan upah rendah dan kondisi buruk, dan pertanian migran. Efek psikologis eksploitas meliputiperasaan tidak berdaya,perasaan malu, rendah diri, syok, hilangnya kepercayaan terhadap orang sekitar dan lingkungannya, kehilangan arah hidup, kebingungan, dan gangguan kecemasan termasuk gangguan stres pasca trauma, fobia, serangan panik, dan depresi (Anwar Fu'ady, 2007).

Perdagangan anak adalah permasalahan yang harus segera ditangani bukan hanya pada permukaannya saja, tetapi penanganannya harus tuntas sampai kepada akarnya. Pengetahuan masyarakat tentang perdagangan anak di Indonesia masih terbatas pada kalangan tertentu.Namun demikian adanya indikasi kuat bahwa hal tersebut semakin meluas dan tidak hanya menyangkut perdagangan didalam batas negara saja tetapi juga ada yang diperdagangkan antar Negara membuat fenomena ini mendapat perhatian dari khalayak ramai.

Orang tua, keluarga dan masyarakat bertanggung jawab untuk menjaga dan memelihara hak anak sesuai kewajiban yang telah diatur di dalam hukum. Demikian juga dalam rangka penyelenggaraan perlindungan anak, negara bertanggung jawab menyediakan fasilitas dan aksesbilitas bagi anak, terutama dalam menjamin pertumbuhan dan perkembangannya secara optimal dan terarah baik fisik, mental, spiritual maupun sosial yang dimaksudkan untuk mewujudkan kehidupan terbaik bagi anak sebagai penerus bangsa.

Indonesia telah mengambil kebijakan untuk meniadakan perdagangan anak, namun implementasi kebijakan tersebut masih dirasa kurang dan memang belum secara maksimal dalam mencegah masalah perdagangan anak ini.Perdagangan anak, (Child Trafficking) di Indonesia telah mendapat perhatian dari berbagai kalangan, antara lain para peneliti, sebagaimana kita temukan dari beberapa literatur hasil penelitian mereka. Irwanto, Ph.D, Psikolog Universitas Atmajaya, Fentiny Nugroho dan Johanna Debora Imelda, melakukan penelitian pada tahun 2001 di empat lokasi - Pulau Bali, Jakarta, Medan, dan Pulau Batam tentang perdagangan anak yang bertujuan antara lain: menggambarkan kebijakan-kebijakan nasional yang relevan dengan masalah perdagangan anak, dan menjelaskan gejala-gejala yang dijumpai dalam perdagangan anak di Indonesia terutama Jakarta, Medan, Bali, dan Batam. Metode penelitian yang digunakan adalah pendekatan kualitatif dengan informan meliputi pejabat pemerintah, penegak hukum, aktivis LSM, pendidik, dan akademisi, serta wartawan.

Kesimpulan penelitian yang dituangkan dalam buku "Perdagangan Anak di Indonesia" 2001 (Irwanto, 2001:126-134) adalah: Karena kompleksnya masalah perdagangan anak, maka perlu upaya menggalang kerja sama melalui kemitraan yang menjadi satu-satunya cara yang harus dikembangkan di masa datang supaya penanganan masalah ini menjadi lebih efektif.

Mengatasi permasalahan perdagangan anak tidak hanya melibatkan satu lembaga, akan tetapi harus melibatkan semua pemangku kepentingan yang ada di masyarakat, yaitu instansi-instansi pemerintah, LSM, organisasi kemasyarakatan yang tergabung dalam sebuah kemitraan yang diperkuat oleh peraturan pemerintah, paling tidak keputusan menteri untuk bersama-sama menangani masalah perdagangan anak. 


\section{Perdagangan Anak}

Perdagangan anak merupakan salah satu bentuk tindakan kejahatan yang dapat dilakukan oleh seseorang atau sekelompok orang atau sebuah lembaga terhadap orang yang usianya belum mencapai 18 tahun, termasuk janin yang masih berada dalam kandungan. Perdagangan anak didefinisikan oleh ODCCP (Office for Drug Control and Crime Prevention) sebagai perekrutan, pemindahan, pengiriman, penempatan atau menerima anak-anak di bawah umur untuk tujuan eksploitasi dan itu menggunakan ancaman, kekerasan, ataupun pemaksaan lainnya seperti penculikan, penipuan, kecurangan, penyalahgunaan wewenang maupun posisi penting.

Perdagangan anak biasanya bertujuan:

- eksploitasi untuk pekerjaan (termasuk perbudakan dan tebusan),

- eksploitasi seksual (termasuk prostitusi dan pornografi anak),

- eksploitasi untuk pekerjaan ilegal (seperti mengemis dan perdagangan obatterlarang),

- perdagangan adopsi,

- perjodohan dengan pemaksaan.

Pelaku dalam perdagangan (trafficking) anak dan perempuan dapat dibedakan dalam 3 (tiga) unsure. Pembedaan dilakukan berdasarkan peranannya masing-masing dalam tindakan perdagangan (trafficking):

Pihak yang berperan pada awal perdagangan;

1. Pihak yang menyediakan atau menjual orang yang diperdagangkan;

2. Pihak yang berperan pada akhir rantai perdagangan sebagai penerima/pembeli orang yang diperdagangkan atau sebagai pihak yang menahan korban untuk dipekerjakan secara paksa dan yang mendapatkan keuntungan dari kerja itu.

Perdagangan anak yang dipahami dalam artikel ini perdagangan manusia:

Perdagangan manusia berarti pengerahan, pengangkutan, pemindahan, penyembunyian atau penerimaan orang dengan menggunakan berbagai ancaman atau paksaan atau bentuk-bentuk lain dari kekerasan, penculikan, penipuan, muslihat, penyalahgunaan kekuasaan atau posisi rentan berupa pemberian atau penerimaan pembayaran atau keuntungan untuk mendapatkan izin dari orang yang memiliki kendali atas orang lain untuk tujuan eksploitasi. Trafiking, menurut ICMC/ACIL tidak hanya merampas hak asasi tapi juga membuat mereka rentan terhadap pemukulan, penyakit, trauma dan bahkan kematian. Pelaku trafiking menipu, mengancam, mengintimidasi dan melakukan tindak kekerasan untuk menjerumuskan korban ke dalam prostitusi.

Pelaku trafiking menggunakan berbagai teknik untuk menanamkan rasa takut pada korban supaya bisa terus diperbudak oleh mereka. Menurut ICMC/ACIL, beberapa cara yang dilakukan oleh pelaku terhadap korban antara lain (ICMC/ACIL-Mimpi Yang Terkoyak, 2005):

1. Menahan gaji agar korban tidak memiliki uang untuk melarikan diri

2. Menahan paspor, visa dan dokumen penting lainnya agar korban tidak dapat bergerak leluasa karena takut ditangkap polisi;

3. Memberitahu korban bahwa status mereka ilegal dan akan dipenjara serta dideportasi jika mereka berusaha kabur

4. Mengancam akan menyakiti korban dan/atau keluarganya

5. Membatasi hubungan dengan pihak luar agar korban terisolasi dari mereka yang dapat menolong

6. Membuat korban tergantung pada pelaku trafiking dalam hal makanan, tempat tinggal, komunikasi jika mereka di tempat di mana mereka tidak paham bahasanya, dan dalam "perlindungan" dari yang berwajib

7. Memutus hubungan antara pekerja dengan keluarga dan teman.

\section{Anak dan Hak Anak}


Menurut Konvensi Perserikatan Bangsa-Bangsa mengenai Hak Anak-anak (United Nations Convention on the Rights of the Child 1989),

"seorang anak berarti setiap manusia yang berusia dibawah 18 tahun.Anak adalah manusia yang belum matang, didefinisikan dalam hukum internasional adalah mereka yang berusia dibawah 18 tahun.Masa kanak-kanak adalah suatu tahapan dalam siklus kehidupan anak sebelum mereka mendapat peran dan bertanggung jawab penuh sebagai orang dewasa"

Masa anak masih memerlukan perhatian dan perlindungan khusus,seiring dengan persiapan menuju pada kehidupan mereka menjadi orang dewasa. Meskipun demikian, setiap kebudayaan memiliki kata yang berbeda untuk berbagai tahapan dalam masa kanak-kanak, dan harapan tentang apa yang dapat dilakukan anak pada masing-masing tahapan.

\section{Faktor Terjadinya Perdagangan Anak \\ Kemiskinan (Permasalahan Ekonomi)}

Semenjak terjadinya krisis ekonomi mulai tahun 1997, semuanya berdampak kepada seluruh elemen masyarakat.Perekonomian semakin sulit, semakin banyak rakyat yang tidak mampu untuk membiayai keluarganya khususnya anaknya. Mulai dari biaya pendidikan, hingga biaya kehidupan sehari-hari sehingga, "kelompok keluarga miskin biasanya mengerahkan seluruh tenaga kerja keluarga termasuk anak-anak untuk memperoleh penghasilan" (Haryadi dan Tjandraningsih, 1995). Kebanyakan anakanak yang harus bekerja tidak punya pilihan lain untuk membantu keluarganya karena mereka tidak mempunyai kesempatan untuk mendapatkan pekerjaan atau memperbaiki ekonomi keluarga mereka masing-masing. Himpitan perekonomian itu membuat keluarga khususnya orangtua semakin mudah terbujuk rayu oleh agen atau pelaku perdagangan anak dengan iming-iming serta janji palsu akan pekerjaan yang dapat membuat hidup lebih baik lagi dengan gaji yang besar. Ketidakjelasan akan pekerjaan juga membuat orang menjadi pasrah dalam menerima pekerjaan untuk dipekerjakan sebagai apa saja dan hal ini yang membuat para pelaku menargetkan anak sebagai korban.

\section{Kurangnya Pendidikan dan Informasi}

Seperti yang tertera di buku Penanggulang Perdagangan Perempuan dan Anak, 2004, "Korban yang biasanya adalah perempuan atau gadis desa dengan pendidikan rendah sering kali tidak menyadari tanda-tanda bahaya dari perdagangan, atau tidak dilengkapi dengan keterampilan, pengetahuan, dan sumber daya untuk bermigrasi dengan aman."Menurut Statistik Indonesia di tahun 2004, anak-anak yang berumur 10 - 14 tahun, tertera bahwa 93,34 persen masih sekolah. Tetapi golongan anak yang berumur 15-19 tahun tertera bahwa hanya 52,77 persen saja yang melanjuti sekolah dan sekitar 47 persen lainnya tidak melanjutkan sekolah.Pendidikan yang memadai tentunya akan sangat membantu masyarakat agar tidak terjebak dalam kasus perdagangan anak. Kekurangtahuan akan informasi mengenai perdagangan anak membuat orang-orang lebih mudah untuk terjebak menjadi korban perdagangan anak khususnya di pedesaan dan terkadang tanpa disadari pelaku perdagangan anak tidak menyadari bahwa ia sudah melanggar hukum. Para korban perdagangan biasanya susah untuk mencari bantuan dinegara dimana mereka dijual karena mereka tidak memiliki kemampuan unutuk menggnakan bahasa dinegara tersebut.

\section{Kurangnya Kepedulian Orang Tua}

Tidak jarang ditemukan orang tua yang kurang peduli untuk membuat akta kelahiran sang anaknya dengan berbagai alasan. Orang tanpa tanda pengenal yang memadai lebih mudah menjadi korban trafficking karena usia dan kewarganegaraan mereka tidak terdokumentasi. Sehingga pelaku dapat melakukan aksinya tanpa khawatir identitas korban tidak mudah terlacak.Anak- anak korban trafficking misalnya, lebih mudah diwalikan ke orang dewasa manapun yang memintanya. 


\section{Usaha Perlindungan Anak Korban Trafficking}

Pemerintah Indonesia telah berusaha melakukan berbagai upaya untuk menangani masalah child trafficking yang terjadi di Indonesia.Namun upaya-upaya yang telah dilakukan oleh pemerintah Indonesia tidak menunjukan hasil yang memuaskan, terbukti kasus child trafficking yang terjadi di Indonesia bukannya menurun malah semakin meningkat. Upaya tersebut dapat dilihat pada:

1. Undang-undang yang relevan untuk memberikan perlindungan kepada korban trafiking, UU No.37/1997 tentang Hubungan Luar Negeri : Undang-undang ini dapat digunakan untuk melindungi orang Indonesia yang diperjualbelikan diluar negeri .

2. Undang no 21. Tahun 2007, Tentang pemberantasan tindak pidana perdagangan orang

3. Undang No. 23 Tahun 2002 tentang Perlindungan Anak pun melarang perdagangan anak. Dimana Tujuan dari perlindungan anak sendiri disebutkan dalam Pasal 3 UU No. 23 Th 2002 :

"Perlindungan anak bertujuan untuk menjamin terpenuhinya hak-hak anak agar dapat hidup, tumbuh, berkembang, dan berpartisipasi secara optimal sesuai dengan harkat dan martabat kemanusiaan, serta mendapat perlindungan dari kekerasan dan diskriminasi, demi terwujudnya anak Indonesia yang berkualitas, berakhlak mulia, dan sejahtera."

4. UNICEF, Convetion On Right Of The Child. (Konvensi Hak-hak Anak)

5. Undang-undang No. 4 (1979) Tentang Kesejahteraan Anak

6. Adanya RPSA (Rumah Perlindungan Sementara Anak), dimana fungsi dari RPSA ini adalah:

- Pemberian pelayanan segera bagi anak yang menghadapi tindak kekerasan dan perlakuan selah (emergency service).

- Perlindungan (Protection).

- Pengembalian keberfungsian sosial anak agar dapat melaksanakan perannya secara wajar (rehabilitiasoan).

- Pemulihan kondisi mental anakakibat tekanan dan trauma (revovery).

- Advokasi.

- Penyatuan kembali anak pada keluarga asli, keluarga pengganti, lembaga lainnya (reunifikasi).

\section{Penutup}

Child trafficking terjadi karena beberapa faktor, yakni kemiskinan, kurangnnya pendidikan dan informasi, serta upaya penegakan hukum di Indonesia yang masih lemah.

Pemerintah Indonesia telah melakukan berbagai kebikajan dalam menangani masalah child trafficking ini, antara lain dengan adanya undang-undang no.21 tahun 2007, undang-undang no.23 tahun 2002, serta dengan adanya Lembaga RPSA (Rumah Perlindungan Sementara anak).

Upaya untuk menangani masalah child trafficking seharusnya dilakukan dalam tiga tingkatan, yakni:

1. Ditingkat komunitas hendaknya memperkuat keterampilan korban dan keluarganya untuk melawan perdagangan anak, lewat pendidikan, pengorganisasian atau advokasi kasus secara individu maupun kolektif.

2. Ditingkat masyarakat, hendaknya ada kampanye dan pendidikan tentang perdagangan anak serta usaha-usaha untuk melawannya.

3. Ditingkat negara hendaknya lobi dan kampanye pada pembuat kebijakan (pemerintah) tentang perubahan hukum dan penegakannya.

\section{Buku:}

\section{DAFTAR PUSTAKA}


Irwanto, Perdagangan Anak di Indonesia, Suatu diskripsi Awal, Jakarta 2001 Hurlock, 1980.Elizabeth, Psikologi Perkembangan, Erlangga, Jakarta , Ollenburge, Jane. 1996. Sosiologi Wanita. Jakarta: Rineka Cipta Sumardi, Mulyanto. 1982. Kemiskinan dan Kebutuhan Pokok. Rajawali: Jakarta Winarno Budi, 2002, Isu-Isu Global Kontemporer, PT. Buku Seru, Yogyakarta

\section{Jurnal:}

Fu'ady, Anwar. Child Abuse Pada Anak Korban Trafficking (Studi Kasus pada Anak Korban Trafficking di Kota Malang)

Profil Rumah Perlindungan Sementara Anak (RPSA), Bambu Apus Jakarta Timur, 2006

Syafaat, Rachmad. Dagang Manusia ; Kajian Trafficking terhadap perempuan dan Anak di Jawa Timur. Yogyakarta : LAPPERA PUATAKA UTAMA, 2003

http://intelektualhukum.wordpress.com/2010/01/14/perdagangan-trafficking-anak-danperempuan/ (4/11/2014)

Undang-Undang RI Nomor 23 Tahun 2002 Tentang Perlindungan Anak

\section{Lainnya:}

UNICEF, Convetion On Right Of The Child. (Konvensi Hak-hak Anak)

Undang-undang No. 4 (1979) Tentang Kesejahteraan Anak

Undang-undang No. 23 Tahun 2005 Tentang Perlindungan Anak 